\title{
Research on the Relationship between Corporate Philanthropy and Audit Fee \\ Qinnan Ruan ${ }^{*}$, Daolin Zha, Bin Li \\ School of Economics and Management, China University of Geosciences, Wuhan, China \\ *Corresponding author: Qinnan Ruan, Master of Accounting, ruanqinnan@vip.qq.com
}

\begin{abstract}
As a response to the increased corporate philanthropy and the consequent corporate philanthropy discourse among researchers, practitioners and policymakers, we study the consequence of corporate philanthropy in an alternative way by the view of auditors. We seek to understand how auditors, the risk-sensitive group, would interpreter the corporate philanthropy behavior from the firms in industry with strong social concerns for harmful pollutants. Using a panel date from Chinese listed company in the chemical industry from 2009 to 2013, this paper finds that despite corporate philanthropy may involve more audit work, it tends to decrease the audit fee. Our paper fills a gap in extant research by building a link between corporate philanthropy and auditor's behavior and can be of interest to firms adopting a strategic corporate philanthropy policy and their stakeholders.
\end{abstract}

Key words: corporate philanthropy; audit pricing; litigation risk; audit effort

\section{Introduction}

Corporate philanthropy has drawn growing attention among researchers, practitioners and policymakers. According to CECP (2016), an international network specialized in corporate philanthropy, the total giving from corporate saw an increase in $47 \%$ firms. As a response to the increasing philanthropy awareness, researchers have explored the donations in various perspectives (Gautier and Pache, 2013). Extant studies mainly focus on the individual level, firm level and social level drivers of corporate philanthropy (Navarro, 1988; Marquis and Lee, 2013; Miller, 2008; Schwartz, 1968; Wang and Qian, 2011). Some studies explore the benefits of corporate philanthropy on shareholder value and consumer choice (Su and He, 2010; Lev et al, 2010). However, few studies pay attention to the reduced expenses brought by corporate philanthropy. We thus lack understanding of the corporate philanthropy strategy (Gautier and Pache, 2013). To address the insufficiency in extant researches, this study considers the audit fee save as a potential benefit (cost) of corporate influenced by corporate philanthropy. To be more specific, we examine the relationship between corporate philanthropy and audit fee using data from high pollutant industry from Chinese listed company in a period from 2009 to 2013. Our results show that corporate philanthropy is negatively associated with audit fee and thus contribute to the literature by filling the gap and can be of interest to firms adopting strategical corporate philanthropy and their stakeholders who may have concerns for the expense of corporate operations.

\section{Literature Review and Hypothesis Development 2.1 Corporate philanthropy and financial risk.}

Besides the much spotlight on the motivations of corporate philanthropy (Navarro, 1988; Marquis and Lee, 2013; Miller,2008; Schwartz,1968; Wang and Qian,2011), recent studies have focused on the strategic character of corporate philanthropy (Maas and Liket,2011), which 
stresses the benefits of corporate philanthropy. Godfrey (2005) develops a conceptual model to argue that managers would allocate some resources in corporate philanthropy as it can generate moral capital and provide stakeholders protection from potential risks and lead to more wealth. Empirical studies support his conceptual model. For example, Su and He (2010) explore the performance of Chinese private firms after a huge earthquake and find a positive association between corporate philanthropy and corporate profitability. Thus, corporate can obtain risk-shield and a like-insurance protection resulting from corporate philanthropy and in better financial performance. In this way, the future financial risks can be reduced and managed through corporate philanthropy.

\subsection{Corporate philanthropy and audit efforts.}

Although the form of corporate philanthropy can be different contingent on manager's own discretion, most forms of philanthropy need to be reflected in firm's financial statement, which involve the work of auditors. Therefore, corporate philanthropy may add potential work of auditors to ascertain the corporate philanthropy-related business process as to ensure the fairness of the financial statement.

\subsection{Audit fee, audit risk and audit efforts.}

Simunic (1980) develops a wild-accepted model in which audit fee is equal to audit cost in a competitive audit market. Following Simunic (1980), Simunic and Stein (1995) finds auditors tend to charge a premium towards clients' litigation risk because auditors face a potential litigation risk which may harm their reputation, one of the most important intangible assets for them. In our study, as corporate philanthropy can reduce firms' potential financial risk, auditors would suffer a reduced legal responsibility thus charge lower audit fees. However, as mentioned, corporate philanthropy can add auditors' efforts leading to increased cost. And auditors have to charge higher audit fees for that.

Therefore, we develop the following hypotheses.

Hypothesis 1: Corporate philanthropy is positively associated with audit fee.

Hypothesis 2: Corporate philanthropy is negatively associated with audit fee.

\section{Research Design}

\subsection{Model and Variables}

To assess the relationship between corporate philanthropy and audit fee, we employ the following regression model based on prior researches (Simunic, 1980; Simunic and Stein, 1995; Wang and Dou, 2015).

$$
\text { AUDFEE }=\beta_{0}+\beta_{1} C P+\sum \delta_{k} \text { CONTROL }_{k}+\varepsilon
$$

Where AUDFEE, our dependent variable, is the nature logarithm of firm's audit fee disclosed in financial statement and CP is a dummy variable that equals 1 if corporate philanthropy and 0 otherwise. We also include several control variables including BIG4, LDR, ROA, CLEAN, SIZE, STATE, SUB and TACCUR based on prior researches (Simunic and Stein, 1995; He et al 2015). 
Among the control variables, BIG4 is a dummy variable that equals 1 if the auditor is one of big 4 accounting firms and 0 otherwise; LDR is the long term debt ratio; ROA is the return on assets; CLEAN is a dummy variable that equals 1 if the audit opinion is clean and 0 otherwise; SIZE is the natural logarithm of companies' total assets; STATE is a dummy variable that equals 1 if the company is state-owned and 0 otherwise; SUB is the square number of subsidiaries and TACCUR is the total accrual of a company divided by total assets.

\subsection{Sample Selection}

We obtain the sample from Chinese listed-companies in the chemical industry to test our hypotheses. Data are available from China Stock Market and Accounting Research Database (CSMAR), a major capital market research database for Chinese listed-companies. We exclude observations with missing value and use the final sample of 522 observations to run the regression.

\section{Results \& Analysis}

Table 1 reports the summary statistics including the mean and median of variables in our model. For the independent variable, the average AUDFEE is 13.27 and the median is 13.18 with a standard deviation of 0.460 . The CP has a mean of 0.430 and a median of 0 . The mean and median for the control variables are presented in Table 1.

\begin{tabular}{llllll}
\multicolumn{6}{l}{ Table 1 - Descriptive statistics } \\
\hline Variable & Mean & SD & Min & Median & Max \\
\hline AUDFEE & 13.27 & 0.460 & 12.42 & 13.18 & 14.95 \\
CP & 0.430 & 0.490 & 0 & 0 & 1 \\
BIG4 & 0.0300 & 0.170 & 0 & 0 & 1 \\
LDR & 0.0700 & 0.100 & 0 & 0.0200 & 0.410 \\
ROA & 0.0400 & 0.0600 & -0.250 & 0.0400 & 0.220 \\
CLEAN & 0.940 & 0.240 & 0 & 1 & 1 \\
SIZE & 21.78 & 0.970 & 19.93 & 21.72 & 24.11 \\
STATE & 0.210 & 0.410 & 0 & 0 & 1 \\
SUB & 2.730 & 1.460 & 0 & 2.450 & 7.550 \\
TACCUR & -0.0100 & 0.410 & -1.030 & -0.0200 & 9.110 \\
\hline
\end{tabular}

If our results support hypothesis 1 , CP should have a positive coefficient, otherwise a negative coefficient. Table 2 shows the regression results of the model. CP's coefficient is negative $(-0.0512)$ and significant $(\mathrm{p}<0.1)$, indicating that there is a negative relationship between corporate philanthropy and audit fee, which support our second hypothesis: Corporate philanthropy is negatively associated with audit fee.

\section{Summary}

In this study, we briefly examine the relationship between corporate philanthropy and audit fees using the data of Chinese listed-company in the chemistry industry. The result is consistent with our second hypothesis, suggesting that corporate philanthropy is negatively associated with audit fee. This means the shield from risk brought by corporate philanthropy can reduce the risk that auditors care when deciding audit fees. Although corporate philanthropy behavior 
may increase auditors' extra work, the result indicates that the overall effect of corporate philanthropy on auditors is reduced fees resulting from reduced work.

For managers and other stakeholders of a corporate, this study points out another benefit of corporate philanthropy in the view of reduced expense of operations. This reduced expense comes along with reduced risk, contributing to the long-term growth of corporate.

Table 2 - Regression results

\begin{tabular}{|c|c|}
\hline VARIABLES & AUDFEE \\
\hline $\mathrm{CP}$ & $\begin{array}{l}-0.0512 * \\
(0.0293)\end{array}$ \\
\hline BIG4 & $\begin{array}{l}1.007 * * * \\
(0.0847)\end{array}$ \\
\hline LDR & $\begin{array}{l}-0.798^{* * *} \\
(0.152)\end{array}$ \\
\hline ROA & $\begin{array}{l}-0.0405 \\
(0.227)\end{array}$ \\
\hline CLEAN & $\begin{array}{l}-0.0452 \\
(0.0590)\end{array}$ \\
\hline SIZE & $\begin{array}{l}0.241 * * * \\
(0.0179)\end{array}$ \\
\hline STATE & $\begin{array}{l}-0.0123 \\
(0.0334)\end{array}$ \\
\hline SUB & $\begin{array}{l}0.0784 * * * \\
(0.0107)\end{array}$ \\
\hline TACCUR & $\begin{array}{l}-0.0206 \\
(0.0325)\end{array}$ \\
\hline Constant & $\begin{array}{l}7.895^{* * *} \\
(0.378)\end{array}$ \\
\hline Observations & 522 \\
\hline R-squared & 0.596 \\
\hline
\end{tabular}

Standard errors in parentheses

*** $\mathrm{p}<0.01,{ }^{* *} \mathrm{p}<0.05,{ }^{*} \mathrm{p}<0.1$

\section{References}

1. CECP. Giving in numbers 2016 edition. New York, NY: Committee Encouraging Corporate Philanthropy. (2016).

2. A. Gautier, and A. C. Pache, Research on corporate philanthropy: a review and assessment. Journal of Business Ethics, 126.3 (2015) 343-369.

3. P. C. Godfrey, The relationship between corporate philanthropy and shareholder wealth: a risk management perspective. Academy of Management Review, 30.4(2005) 777-798.

4. K.He, X. Pan, G. G. Tian, Legal Liability, Government Intervention, and Auditor Behaviour, Evidence from Structural Reform of Audit Firms in China. European Accounting Review, (2015) 1-35. 
5. B.Lev, C. Petrovits, , and S. Radhakrishnan, Is doing good good for you? how corporate charitable contributions enhance revenue growth. Strategic Management Journal, 31.2 (2010) 182-200.

6. K.Maas, and K. Liket, Talk the walk: measuring the impact, of strategic philanthropy. Journal of Business Ethics, 100.3 (2011) 445-464.

7. C. Marquis, and M. Lee, Who is governing whom? executives, governance, and the structure of generosity in large u.s. firms. Strategic Management Journal, 34.4 (2013) 483-497.

8. J. Miller, The ongoing legitimacy project: corporate philanthropy as protective strategy. European Management Review, 5.3 (2008) 151-164.

9. P.Navarro, Why do corporations give to charity? Journal of Business, 61.1 (1988) 65-93.

10. R. A. Schwartz, Corporate philanthropy contributions. The journal of Finance, 23.3 (1968) 479-497.

11. D. Simunic, The Pricing of Audit Services: Theory and Evidence. Journal of Accounting Research, 18.1 (1980) 161-190.

12. D. A. Simunic, and M. T. Stein, The impact of litigation risk on audit pricing: a review of the economics and the evidence. Auditing A Journal of Practice \& Theory, 15 (1995).

13. J.Su, and J. He, Does giving lead to getting? evidence from Chinese private enterprises. Journal of Business Ethics, 93.1 (2010) 73-90.

14. H.Wang, and C. Qian, Corporate philanthropy and corporate financial performance: the roles of stakeholder response and political access. Academy of Management Journal, 54.6 (2011) 1159-1181.

15. C.Wang, and H. Dou, Does the transformation of accounting firms' organizational form improve audit quality? evidence from China, China Journal of Accounting Research, 78.4 (2015) 279-293. 